University of Nebraska - Lincoln

DigitalCommons@University of Nebraska - Lincoln

Space, Cyber, and Telecommunications Law

Program Faculty Publications

2002

\title{
Earth Observation Data Policy in Europe: An Inventory of Legal Aspects and Legal Issues
}

Frans von der Dunk

University of Nebraska - Lincoln, fvonderdunk2@unl.edu

Follow this and additional works at: https://digitalcommons.unl.edu/spacelaw

Part of the Air and Space Law Commons

von der Dunk, Frans, "Earth Observation Data Policy in Europe: An Inventory of Legal Aspects and Legal Issues" (2002). Space, Cyber, and Telecommunications Law Program Faculty Publications. 16.

https://digitalcommons.unl.edu/spacelaw/16

This Article is brought to you for free and open access by the Law, College of at DigitalCommons@University of Nebraska - Lincoln. It has been accepted for inclusion in Space, Cyber, and Telecommunications Law Program Faculty Publications by an authorized administrator of DigitalCommons@University of Nebraska - Lincoln. 
Published (as chapter 3) in Earth Observation Data Policy and Europe, edited by Ray Harris (Lisse: A. A. Balkema, 2002), pp. 19-28. Copyright ( 2002 Swets \& Zeitlinger B.V. (Division of Taylor \& Francis). Used by permission.

\title{
Earth Observation Data Policy in Europe: An Inventory of Legal Aspects and Legal Issues
}

\author{
Frans von der Dunk
}

International Institute of Air and Space Law, Leiden University, The Netherlands

\begin{abstract}
The activities of Earth observation and further policy initiatives to deal with the data produced thereby raise fundamental questions as to how to use "law" as a policy tool, to stimulate them and/or curb their perceived negative effects. The crucial involvement of "outer space" in Earth observation causes special legal parameters to arise in this respect. Europe is one of the major players in this area, with various important international organizations involved in addition to a number of space powers, which makes it interesting in particular to deal with the situation in this part of the world. This chapter provides an overview of the major legal parameters which, in the European context, would be conducive or, on the contrary, obstructive for the generally desired gradual and balanced establishment of a market for Earth observation data.
\end{abstract}

\section{Introduction}

The purpose of this chapter is to provide an inventory of the major legal aspects and issues involved in Earth observation data policy in the European context. It does so first by outlining a few preliminary parameters for Earth observation data policy within Europe. This includes a succinct subdivision of "Earth observation activities" as a general category into legally relevant sub-categories of activities. Second, the chapter briefly evaluates the international legal framework within which all Earth observation is undertaken, as regards both general public international law and the more specific regime of space law. Third, it outlines the special legal dimensions that "Europe" brings to the issue of Earth observation data policy in an institutional sense. Particularly relevant in this case is, of course, the European Community's legal framework. Fourth, a few major legal issues involved in a substantive sense in Earth observation activities will be outlined, such as licensing, liability, intellectual property rights and privacy. This is also where the special case of very high-resolution data will come into its own. Fifth and finally, a few aspects not yet dealt with in legal terms vis-à-vis Earth observation (related) activities, but nevertheless having important consequences for Earth observation data policy issues, will be dealt with, such as national and international security and environmental protection. 


\section{Parameters for Earth Observation Data Policies in Europe}

The two most important parameters for the current analysis have been provided by the two primary objectives of the EOPOLE project noted in Chapter 1. Firstly, a strong user perspective should be behind the discussion of the pertinent issues, as well as a major guiding factor in providing answers to relevant questions and guidelines for future activities. Discussion of legal aspects should focus on those Earth observation data issues that are presently or at least in the foreseeable future of real importance for the users.

Secondly, the European perspective on Earth observation data policies should be reiterated as a major parameter. Analysis and discussion should focus largely on the European interests in Earth observation data and related activities and on European obstacles and opportunities in this field. Consequently, United States' and Russian experiences, for example, should only enter the debate in case of clear relevance for the European dimension to Earth observation data policies.

A third parameter of importance relates to the various measures of privatization discernible in the Earth observation field. There may be little doubt that privatization as a concept is beneficial to the further exploitation of space including Earth observation activities. Yet, a balance between the interests of private enterprise in undertaking certain Earth observation related activities and the interests of the public at large in (for instance) safe, nonviolent and non-polluting Earth observation activities should be struck. ${ }^{1}$

The fourth and final parameter to bear in mind during this analysis deals with the subdivision of the Earth observation sector into a few distinct and legally relevant categories of activities. Earth observation from this perspective sensu lato consists of the following sets of activities. 1) The development and production of spacecraft and instruments used for Earth observation. 2) The launch and actual operation of the spacecraft, including the core activity of Earth observation itself. 3) Activities consecutive to the creation of data in the strict sense, such as downlinking, reception, and value adding on Earth. 4) Marketing and sales activities related to the data once these are fit for use by entities not involved and experienced in any Earth observation activities themselves.

\section{The International Legal Framework for Earth Observation Activities}

International law fundamentally hinges upon the sovereignty of states, and operates as a public system. States are given rights and obligations under international law, states are the primary makers and breakers of it, and states have their own responsibility to use their jurisdiction (territorial or personal) to make relevant categories of non-state actors abide on a domestic level by the relevant international rules as well.

As a consequence, public international law is essentially inter-state law. Internally, state sovereignty results in the exclusivity of legal control over state territory, which includes the territorial waters and the national airspace. Thus, this international framework also results in the existence of a number of areas outside any national territorial sovereignty - notably the high seas, Antarctica, and outer space (Article II, Outer Space Treaty ${ }^{2}$ ). For these areas,

1 See for more general aspects of this issue: Dunk, F. G. von der (1998) Private Enterprise and Public Interest in the European "Spacescape." Leiden: International Institute of Air and Space Law. 
it is the community of states as a whole that provides the legal regime and determines what is allowed and what is not. States can only exercise jurisdiction in outer space with regard to their nationals (personal jurisdiction), or, as specifically provided for by space law itself, with regard to registered space-objects (quasi-territorial jurisdiction) (Article VIII, Outer Space Treaty).

Therefore, as a special realm of the legal world, outer space enjoys a special regime comprised in the term "space law," developed on the basis of the Outer Space Treaty. This does not mean, however, that other international legal regimes would have no legal impact in or with respect to space or space activities. Furthermore, it should be realized that most activities in space are still of a remote-controlled character, although this is changing with the development of the International Space Station. The persons or entities actually undertaking space activities (who provide the main point of attachment of legal rules) are usually on Earth, and hence find themselves within some state's territorial jurisdiction.

The most fundamental rule of space law next to the absence of national territorial sovereignty in outer space (and actually following very much from it) is the principle of freedom of space activities (Article I, Outer Space Treaty). This provides the starting point for any discussion on space law: everything that is not, in one way or another, prohibited or conditioned, is allowed. This includes, obviously, the activity of using satellites for Earth observation purposes. The Outer Space Treaty itself provides a few principles to which space activities should conform. Examples concern international cooperation, the prohibition to station weapons of mass-destruction in outer space, the supervision and authorization of private space activities, and sincere efforts to minimize harmful effects of one's space activities (for example, as to the environment) (Articles III, IV, VI, IX, Outer Space Treaty).

More in particular, states are held responsible without further qualification for private space activities carried out under their aegis (Article VI, Outer Space Treaty). They are held liable as well for damage caused by space objects involved in such private activities (in addition of course to liability for damage caused by their own space objects) (Article VII, Outer Space Treaty). The latter regime has been further elaborated by means of the Liability Convention of $1972 .^{3}$

The issue of Earth observation (or, as it is phrased in a slightly more comprehensive term, "remote sensing") at the global level has only been dealt with in some detail by the United Nations General Assembly Resolution 41/65, adopted by consensus on 3 December 1986 (see Appendix C). The Resolution acknowledges the freedom of remote sensing activities, as one particular manifestation of the freedom of space activities subject only to international law. The UN Principles are examined in detail in the next chapter.

2 Treaty on Principles Governing the Activities of States in the Exploration and Use of Outer Space, including the Moon and Other Celestial Bodies (hereafter Outer Space Treaty), London/ Moscow/Washington, adopted 19 December 1966, opened for signature 27 January 1967, entered into force 10 October 1967; 6 ILM 386 (1967); 18 UST 2410; TIAS 6347; 610 UNTS 205.

3 Convention on International Liability for Damage Caused by Space Objects (hereafter Liability Convention), London/Moscow/Washington, adopted 29 November 1971, opened for signature 29 March 1972, entered into force 1 September 1972; 10 ILM 965 (1971); 24 UST 2389; TIAS 7762; 961 UNTS 187. 


\section{European Legal Dimension to Earth Observation Activities}

The efforts at international or even supranational integration which have been undertaken within Europe since World War II have led to the existence of three international organizations which together provide Earth observation in its widest sense in the European context with its own extra legal dimension. All three, in spite of their obvious differences on many counts, ultimately are based on the sovereign consent of the member states to delegate certain competencies to an international organization.

From a space law point of view, firstly the European Space Agency (ESA), established in 1975 by the ESA Convention, ${ }^{4}$ is of importance. At present, 15 European states are members of ESA: Austria, Belgium, Denmark, Finland, France, Germany, Ireland, Italy, the Netherlands, Norway, Portugal, Spain, Sweden, Switzerland, and the United Kingdom. Two of those states - Norway and Switzerland - are not members of the European Community, whereas vice versa two European Community members - Greece and Luxembourg - are not members of ESA. The non-European state of Canada, in addition, has a long-standing institutionalized partnership with ESA.

ESA is entrusted with joint research and development programs of an exclusively peaceful nature (Article II, ESA Convention). Individual member states offer such programs for the purpose of allowing other states to join (and to make them share the costs thereof), while ESA itself also has the competence to propose programs. Article V of the ESA Convention represents the nucleus of ESA's role in the European space endeavor. It provides a framework that allows for flexibility in accommodating the desires of individual states to join certain space programs at a certain level of involvement. At the same time, by means of this framework it maintains a coherent and efficient manageable space program on the international plane.

The second organization of importance in this context is EUMETSAT that was established in 1983 by means of the EUMETSAT Convention. ${ }^{5}$ It currently has 17 member states: the 15 members of ESA plus Greece, as well as a non-European Community member, Turkey. The major task of EUMETSAT is to continue the Meteosat program, developed and hitherto operated by ESA. As a consequence, EUMETSAT is currently only involved in remote sensing for meteorological purposes, and not for Earth observation purposes such as agricultural, environmental, or cartographic ones.

From a legal perspective it is important to note that both ESA and EUMETSAT are interstate, inter-governmental as well as operational organizations: they pool material resources of individual member states and act as mechanisms to prevent inefficient duplication of activities within individual member states. In both cases, the member states did not bequeath the international organizations with anything like independent regulatory authority and competencies. Legal rules and competencies developing within the two re-

4 Convention for the Establishment of a European Space Agency (hereafter ESA Convention), Paris, done 30 May 1975, entered into force 30 October 1980; 14 ILM 864 (1975).

5 Convention for the Establishment of a European Organization for the Exploitation of Meteorological Satellites (EUMETSAT) (hereafter EUMETSAT Convention), Geneva, done 24 May 1983, entered into force 19 June 1986; as amended 14 July 1994, entered into force 27 July 1994; Cmnd. 9483; Space Law - Basic Legal Documents, C.III.1; 44 Zeitschrift fur Luft- und Weltraumrecht (1995), at 68. 
spective frameworks, therefore, can only be implemented with the clear consent of all member states, and remain the exception rather than the rule.

For the European Community (as the legally relevant pillar of the European Union), there is a difference. As a supranational halfway house between a traditional international organization and a federation-like structure, it effectively pools the regulatory efforts of the member states. This has gone so far that actually the sovereignty of the individual member states has been noticeably lessened by this "leaking away" of many sovereign competencies to the partly supra-national level.

At present, 15 European states - Austria, Belgium, Denmark, Finland, France, Germany, Greece, Ireland, Italy, Luxembourg, the Netherlands, Portugal, Spain, Sweden and the United Kingdom - have subjected themselves to a very extensive set of rights and obligations towards each other in the framework of the European Community. This was achieved through signature and ratification of the Treaties of Paris and Rome in the 1950s and subsequent treaties such as the Single European Act of 1986 and the Treaty on European Union of $1992 .{ }^{6}$ Most recently, the Treaty of Amsterdam entered into force, solidifying these various constituent treaties into one and in the process renumbering all the Articles. ${ }^{7}$

Together these treaties form a body of primary Community law, inter alia creating the main Community organs. Furthermore, the treaties provided these organs with extensive legal competencies that amount in a number of cases to supranational powers. Finally, the Community organs themselves extended the substance of European law. With the primary Community law created by the member states as a basis, these organs jointly established the immense body of secondary Community law.

These essential elements of the Community legal order present the Community with its own measure of jurisdiction over a wide range of economic or economy-related activities, including in principle Earth observation (related) activities. Community jurisdiction moreover can be directly applied not only to the member states themselves, but also to private persons and entities otherwise residing under the domestic jurisdictions of these member states.

On economic issues the power of an individual state to legislate has thus largely been transferred to - or at least circumscribed at - the Community level. Under Community law private entities, in contrast to their position under international space law, are definitely subjects in their own right. To a major extent, a distinct and partly supranational jurisdiction of the Community has thus replaced the individual jurisdiction of the member

6 Treaty establishing the European Coal and Steel Community (hereafter Treaty of Paris), Paris, done 18 April 1951, entered into force 23 July 1952; 126 UNTS 140; Treaty establishing the European Atomic Energy Community, Rome, done 25 March 1957, entered into force 1 January 1958; 298 UNTS 167 and Treaty establishing the European Economic Community, Rome, done 25 March 1957, entered into force 1 January 1958; 298 UNTS 11 (hereafter Treaties of Rome); Single European Act, Luxembourg/The Hague, done 17/28 February 1986, entered into force 1 July 1987; 25 ILM 506 (1986); and Treaty on European Union, Maastricht, done 7 February 1992, entered into force 1 November 1993; 31 ILM 247 (1992).

7 Treaty of Amsterdam Amending the Treaty on European Union, the Treaties Establishing the European Communities and Certain Related Acts (hereafter Treaty of Amsterdam), done 2 October 1997, entered into force 1 May 1999; CONF 4005/97, of 23 September 1997. The present chapter follows the Article-numbers according to the amendments resulting from the Treaty of Amsterdam. 
states. The Community organs have partially taken over the law-creating role of the individual member states.

Limitations to the Community's competence vis-à-vis Earth observation would thus largely arise on the level of general substance activities. These limitations emanate from Community law as interpreted in accordance with the notion of "subsidiarity" (Article 8(5), Treaty on European Union). If doubt arises whether an issue could be regulated more effectively and logically at the European level or at the national level, the presumption under "subsidiarity" is that the domestic level should prevail.

As a result, unless the competence to legislate on a certain issue has unequivocally (even if only implicitly) been transferred to the Community's organs, the relevant power should be deemed to rest with the national governmental authorities. In other words, only to the extent that Earth observation activities are clearly covered by provisions in primary or secondary Community law, can any competence to legislate with respect to them, be exercised by Community organs. Thus, Earth observation activities fall within the Community legal order essentially because (and to the extent that) they form a category of economic activities in general. From this perspective, a few fundamental regimes of Community law would have a substantial impact upon such activities.

In a substantive sense, the central and most comprehensive aim of Community integration remains the creation and maintenance of a common market (Articles 2, 3, EC Treaty). While only the internal market, being one side of the common market was established as of 1993, the result amounts to a free market regime (Articles 13-19, Single European Act). This regime in turn is based upon four freedoms (Articles 23-69, EC Treaty), a competition regime (Articles 81-89, EC Treaty), and harmonization of relevant national legislation (Article 95, EC Treaty). In addition, any future realization of a common market would call for external competence of the Community organs in relevant matters (Articles, 2, 3, 10, 308, EC Treaty) - but largely this is still a political rather than a legal issue.

\section{Legal Issues in Earth Observation Activities and Data Policy}

Policy, whether national or international, for a large part makes use of legal instruments and concepts. This is no different in principle for Earth observation activities, including issues of Earth observation data and the enhancement of their usage. At the outset, a few general legal issues in a substantive sense offer themselves for closer scrutiny.

\subsection{Licensing}

A major instrument of policy, especially vis-à-vis private enterprise, is the concept of licensing. Licensing certain activities, or licensing certain entities to undertake certain activities, is an efficient means to control, legally as well as factually, those activities. It allows states to live up to their international responsibility, for example, under space law (Article VI, Outer Space Treaty). Also, international liability can be taken care of, for example, through provisions on reimbursement or obligatory insurance.

Licensing in general is an asset usually only of states, which have the full sovereign legal machinery to legislate, implement, enforce, and adjudicate licensing issues. Even within the European Community, supranational licensing usually takes the form of Com- 
munity standards and requirements for licensing to which national licensing processes would have to conform (Satellite Directive of $1994^{8}$ ). On the other hand, opportunities abound within the Community's legal framework to establish such a centralized licensing structure also on the international plane - as the satellite communications market within the European Community makes clear.

Furthermore, when it comes to operational organizations such as ESA and EUMETSAT, licensing as such might perhaps not form part of their competencies. Yet, their central position in certain areas of activities and the contracts that they conclude as a consequence with other entities (state or non-state) could give them an instrument rather similar to that of licensing. This would apply for example, to the downstream use of Earth observation data involving space operations conducted by those organizations.

In this respect, reference can be made in particular to the possibility of licensing Earth observation activities for their space part through registration of the relevant spacecraft and the consequent entitlement to exercise jurisdiction over it (Article VII, Outer Space Treaty; Registration Convention ${ }^{9}$ ). Since this space part of Earth observation is clearly an indispensable prerequisite for any creation of Earth observation data and consequent Earth observation data activities, it might also present a useful tool for any policies to be implemented in that respect.

\subsection{Liability}

A second important aspect of Earth observation activities sensu lato concerns liability, as the legal accountability of a person or entity for damage caused to another person or entity as defined and regulated by a particular set of rules and principles. Both under public international law and in national legal systems a large number of liability regimes for specific activities, areas, situations and entities exist.

Especially in the case of space activities, including those underpinning the Earth observation sector, such liability regimes present a powerful regulatory and policy tool, in view of the large risks of failure and the large risk of catastrophic damage compared with other sectors of human activity. Experience in the United States launch services business has shown that, for example, the way in which the question of limitation of liability is dealt with plays a crucial role in private interest in this sector.

At this point, it seems that, internationally speaking, the sole liability regime of interest for Earth observation is the space law liability regime, as elaborated in the Liability Convention of 1972. Operation of the liability regime contained in it, however, is triggered by the damage being caused "by a space object," which is usually taken to mean by means of physical impact (Article I(a)). Thus, it would not seem to include damage caused by flawed data created in outer space - at least not yet.

On the other hand, while the required competencies could no doubt be easily found within national jurisdictions, it might be questioned whether at present any national liability regime deals in any reasonably specific manner with Earth observation and/or data

8 Commission Directive amending Directive 88/301/EEC and Directive 90/388/EEC in particular with regard to satellite communications, 94/46/EC, of 13 October 1994; OJ L 268/15 (1994).

9 Convention on Registration of Objects Launched into Outer Space (hereafter Registration Convention), New York, adopted 12 November 1974, opened for signature 14 January 1975, entered into force 15 September 1976; 14 ELM 43 (1975); 28 UST 695; TIAS 8480; 1023 UNTS 15. 
distribution at all. Thus, only general national legal concepts such as "due care," "negligence," "gross negligence," or "willful misconduct" could be discerned, whose application to the Earth observation data business would be - to say the least - uncertain, ad hoc and dependent upon interpretation a posteriori rather than a priori.

\subsection{Intellectual property rights}

A third point of interest for Earth observation activities, this time more focused on the data distribution issue, relates to intellectual property rights. Intellectual property rights for the present analysis is a generic term, encompassing copyrights (for written or otherwise "created" materials) and patents (for inventions) as the most common specific forms of intellectual property rights. Any intellectual property rights regime has as its basic tenet the protection of someone's pioneering and inventing work against potential profiteers benefiting from such work without any effort of their own. The stimulation of pioneering and inventing efforts should be maintained. However, in the end society at large is also supposed to benefit from such pioneering and inventing efforts. No pioneer or inventor should have an inherent right to an eternal monopoly regarding his or her work; any regime should strike a balance in this respect.

For such a regime to be internationally and comprehensively effective, it should operate in two ways. It should apply both to materials created or invented in space, in order not to discourage pioneers "out there," and to mimicry and disallowable usage in space, in order to discourage profiteers from dodging Earthly restrictions by moving their mimicry and usage to that area. The latter possibility is currently not feasible due to the high cost of producing anything in outer space, although this may change in the future.

As to its much more feasible complement, in order to maximize effectiveness of an intellectual property rights regime, efforts to harmonize national legislation on this issue are required. National regimes on the issue are usually territorial in scope, whether this concerns the territory where the intellectual property is devised and/or registered, or the territory where the violations of applicable rights occur. One consequence of the terra communis status of outer space (Article II, Outer Space Treaty) is that the normal operation of copyrights and patent rights regimes would be severely curtailed if data were physically conceived, created, or invented in outer space.

As for Earth observation data activities and database protection specifically, initially it was ESA that undertook an effort to harmonize national legislation on the issue. The major shortcomings of ESA in this field, which soon became clear, stem from its circumscribed role in legal terms. The tools were provided to impose a certain regime only where ESA itself was an indispensable participant, for example in the European Remote Sensing Satellite (ERS) program. The opportunity to play such a role, however, is consistently diminishing with budget cuts on the national level for space programs, especially those undertaken within the ESA framework.

In 1990 ESA started a research project on the legal problems of remote sensing data protection, when it became clear that its own competencies were too limited for comprehensive action. The Commission became interested in intellectual property rights as anticompetitive tools. A study for the Commission resulted in recommendations to make the then draft Directive on the Protection of Databases applicable to remote sensing data. ${ }^{10}$

10 "Conditions of Access to Earth Observation Data: Legal Aspects," April 1993, EC study under the direction of Prof. P. Gaudrat. 
Thus, the resulting Directive 96/9/EC of 11 March 1996 established a sui generis right of database protection. It obliges the member states to include databases, including those containing Earth observation data, in their national intellectual property rights regimes, in conformity with a number of parameters further provided by the Directive itself. Interestingly, the Directive applies to both "Community nationals" and "Community territory" (Article 11).

\subsection{Privacy}

The fourth interesting legal area for debate concerns that of privacy. It is particularly here that the special opportunities provided by the availability of very high-resolution data require special attention. Earth observation, particularly very high-resolution sensing, can easily intrude, in practical terms at least, into the privacy of individuals or other legal entities. Whether it also amounts to intrusion in legal terms, depends rather on the various (national) regimes dealing with privacy questions.

At this point, it would be fair to say that such national regimes have not really dealt with the possibility of intrusion into privacy by the "mere" act of observation from outer space. It will thus be largely a matter of lex ferenda. At the same time, of course, this would open up interesting opportunities to actually implement certain policies with regard to Earth observation data distribution. Stringent privacy-respecting regimes could provide insurmountable obstacles to a policy designed to enhance the widespread use of Earth observation data, and vice versa regimes relaxed on privacy protection could rather stimulate such a policy implementation.

In the absence moreover of any effective international regime overruling the national regimes on the important aspects, the possibility of "legislative competition" would arise, that is, competition between states to enhance the Earth observation data market by means of liberal regimes. In addition, from a practical point of view, issues of jurisdiction arise - which courts allow which claims to be heard, and under which laws, also if brought forward by non-nationals in the state whose courts are concerned.

\subsection{Evidential value}

A fifth issue, in a sense a special manifestation of the fourth one, concerns the evidential value of Earth observation data. From a practical point of view. Earth observation data can nowadays serve as evidence, for example against polluters of the seas. Whether such evidence would be admissible in court, however, is quite another matter (especially in view of the usual absence of experience and knowledge among magistrates with this ultra-modern and high technology type of evidence), and would depend on national rules on court proceedings.

\section{Conclusions}

In structural terms, the dichotomy between the international legal realm of outer space, where no sovereignty applies, and the various national territories, where sovereignty rules supreme, is essential for an understanding of how and where law could operate as a 
policy instrument. Even the special legal dimension that is provided by the Community's legal regime has to be understood from this perspective.

In this light, the fourfold sub-division of Earth observation in categories of activities is of paramount importance (see section 2 of this Chapter). On the first category (of research and development, and production), it appears that it would present a too remote and too indirect point of attachment of legal rules for the purposes of data policies to merit extensive evaluation. Even the only reasonably elaborated concept, of product liability, would not seem to bear any significance from that perspective. In either case, on this category national law rules supreme, and international law would operate as a harmonizing factor at best - with all its attendant difficulties.

On the second category (of the space operations), legal regulation is more international in character than in the other cases. This obviously has to do with the fact that the international area of outer space is directly involved here. Admittedly, as mentioned, individual states' territorial sovereignty - next to jurisdiction over nationals and over registered space objects - remains a potent tool in view of the remote-controlled character of the activities comprising this category. Nevertheless, the space part of Earth observation presents the most likely direct target for international law and internationally harmonized national legislation, in view of it being indispensable for the third and fourth categories down-stream where the Earth observation data themselves are concerned.

On these third and fourth categories (of the post-space activities), the national component in regulation becomes more important again. International law in these areas would have to operate through the mechanism of harmonization of national legal regimes. On the other hand, it is precisely here where the possibilities of the Community's legislative machinery could operate for the benefit precisely of the aforementioned purpose. 